\title{
MODEL KOLABORASI GURU, SISWA, DAN KELUARGA (KOGUSIGA) MENINGKATKAN PENGETAHUAN DAN KETERAMPILAN GURU TENTANG KEAMANAN MAKANAN ANAK SEKOLAH
}

\author{
Sigit Mulyono ${ }^{1 *}$, Elly Nurachmah ${ }^{1}$, Junaiti Sahar $^{1}$, Sabarinah Prasetyo $^{2}$ \\ 1. Fakultas Ilmu Keperawatan Universitas Indonesia, Depok 16424, Indonesia \\ 2. Fakultas Kesehatan Masyarakat Universitas Indonesia, Depok 16424, Indonesia \\ *E-mail: sigit@ui.ac.id
}

\begin{abstract}
Abstrak
Masalah kesehatan akibat makanan yang tidak aman di Indonesia masih sering terjadi, terutama pada kelompok anak usia sekolah untuk itu dikembangkan sebuah model yang melibatkan pihak sekolah, orang tua dan siswa. Penelitian ini merupakan bagian dari sebuah penelitian besar. Tujuan penelitian ini adalah menguji pengaruh model kolaborasi guru, siswa, dan keluarga (KOGUSIGA) terhadap peningkatan pengetahuan dan keterampilan guru tentang keamanan makanan pada siswa Sekolah Dasar (SD). Penelitian ini menggunakan desain eksperimen semu dengan pre-post test dengan menggunakan kelompok kontrol. Subjek sampel penelitian menggunakan total sampling sebanyak 28 responden guru. Kelompok intervensi diberi perlakuan berupa proses kelompok yang dilakukan selama 10 minggu sebagai implementasi model KOGUSIGA dengan kelengkapan modul untuk guru. Hasil penelitian menunjukkan model KOGUSIGA berpengaruh secara signifikan terhadap peningkatan pengetahuan $(p=0,003)$ dan keterampilan $(p=0,015)$ guru tentang keamanan makanan pada anak usia sekolah. Model KOGUSIGA diharapkan dapat menjadi program intervensi dalam Usaha Kesehatan Sekolah (UKS) dan disarankan perawat kesehatan sekolah menjadi koordinatornya.
\end{abstract}

Kata kunci: Anak usia sekolah, guru, keamanan makanan, kolaborasi, perawat UKS

\begin{abstract}
Improvement of Knowledge and Skills Related to Food Safety for School Age Children Through Teacher, Student and Family Collaboration (KOGUSIGA) Model. Food insecurity, especially in school-age children often caused health problems. The purpose of this study was to determine the effect of collaboration model for teachers, students, and families (KOGUSIGA) toward knowledge and skills of teachers about food safety in elementary school students (SD). This study applied quasi-experiment design pre-posttest with a control group. The total sampling included 28 teachers. Intervention was provided over 10 weeks and supported by modules for the teachers. The results showed that KOGUSIGA mode significantly affected on knowledge ( $p=0.003$ and the teachers' skills $(p=0.015)$ about food insecurity. It is concluded that KOGUSIGA model tends to promote food safety for students. It is expected that KOGUSIGA model applied under school health nurses' supervision.
\end{abstract}

Keywords: School age children, teachers, food safety, collaboration, school nurse

\section{Pendahuluan}

Anak usia sekolah (AUS) adalah masa ketika anak berusia 6 sampai 12 tahun (Brown, Isaacs, Krinke, Lechtenberg, \& Murtaugh, 2005). Perkembangan motorik anak pada usia ini sangat cepat tetapi belum seimbang dengan perkembangan intelektualnya, yaitu AUS mulai mengembangkan pemikiran logis meski masih terikat pada fakta-fakta perseptual (Brown, et al., 2005; Piaget, 1969 dalam Wong, Eaton, Wilson, Winkelstein, \& Schartz, 2008). Oleh karena itu, AUS belum dapat memprediksi tingkat bahaya, termasuk tingkat bahaya makanan yang tidak aman (Brown, 2005; Siburian, 2012). Hal tersebutlah yang membuat AUS 
sering mengalami berbagai ancaman kesehatan yang berkaitan dengan keamanan makanan seperti penyakit makanan (foodborn disease), bahan makanan yang mengandung zat berbahaya, dan asupan gizi yang kurang dari kebutuhan (FAO/WHO, 2002).

Kasus kesehatan yang terjadi karena rendahnya keamanan makanan masih banyak terjadi. Hasil konferensi keamanan makanan tingkat Asia yang diselenggarakan di Malaysia tahun 2004 menginformasikan bahwa kejadian penyakit akibat bawaan makanan seperti diare masih menjadi prioritas utama. Makanan yang tercemar khususnya oleh mikroorganisme menjadi penyebab utamanya (FAO/WHO, 2004). Akibat dari tercemarnya makanan oleh bakteri E.Colli menyebabkan lebih dari 3950 kesakitan dan 53 kematian di negara Eropa pada tahun 2011 (EFSA, 2012).

Kasus keracunan makanan juga terjadi di India yang menyebabkan 23 anak sekolah dasar meninggal dunia (NIDM, 2013). Kasus kesehatan akibat keamanan makanan pada anak-anak di Indonesia juga masih cukup tinggi. Berdasarkan hasil penelitian Andarwulan, Madanijah, dan Zulaikhah (2008), di Indonesia masalah kesehatan akibat makanan dialami oleh $21,4 \%$ anak secara keseluruhan, dimana 75,5\% diantaranya dialami oleh kelompok anak usia sekolah dengan kasus yang paling sering dialami adalah keracunan makanan.

Selain kasus kesehatan karena penyakit bawaan makanan, kasus kesehatan karena asupan gizi kurang juga masih cukup tinggi. Berdasarkan penelitian pada tahun 2011 dari 517 SD/ MI di Kota Depok terdapat 1.048 anak bertubuh kurus dan sebanyak tujuh anak gizi kurang (sangat kurus) (Dinkes Depok, 2012). Hasil survei di salah satu sekolah dasar di Depok menemukan bahwa terdapat 36,76\% kasus kurang gizi (Kusumaningsih, Sahar, \& Mulyono, 2010). Selain kasus kesehatan, kasus makanan berbahaya di kota Depok juga masih marak terjadi. Penelitian yang dilakukan oleh BPOM Depkes RI di Kota Depok dari tahun 2006 hingga 2012, dengan mengambil sampel jajanan anak sekolah di 72 Sekolah Dasar (SD) dari 6 kecamatan, mendapatkan hasil bahwa 43 dari 72 SD yang hasil sampel pangannya menunjukkan kandungan bahan berbahaya seperti formalin, boraks, dan pewarna tekstil (Dinkes Depok, 2012).

Kondisi tersebut mendorong agar upaya pemenuhan kebutuhan gizi dan keamanan makanan dapat ditingkatkan semaksimal mungkin. Salah satu yang diupayakan oleh WHO adalah Global Strategi for Food Safety, dengan strategi utamanya dengan pemberian promosi kesehatan. Sayangnya, di Indonesia program promosi kesehatan masih berjalan terpisah sehingga hasilnya belum optimal. Upaya menuju pendekatan yang komprehensif dan integratif sebelumnya sudah dikenalkan oleh Kementerian Kesehatan RI (2014) melalui pendekatan Advokasi, Bina suasana, dan Gerakan model pemberdayaan masyarakat (ABG). Namun, ABG belum berhasil meningkatkan status kesehatan siswa. Perlu peran tenaga kesehatan, dalam hal ini perawat untuk mengoptimalkan upaya tersebut. Sebuah penelitian yang mengembangkan model asuhan keperawatan kesehatan sekolah yang bertujuan meningkatkan peran perawat dalam mengolaborasikan peran guru, siswa, dan keluarga untuk memicu perubahan menuju praktik keamanan makanan telah dilakukan, yaitu model KOGUSIGA (Kolaborasi Guru, Siswa, dan Keluarga). Artikel ini adalah bagian penelitian tersebut dengan fokus pada guru. KOGUSIGA menekankan pada program food safety untuk membangun budaya memilih, mengelola, dan mengkonsumsi makanan yang sehat dan aman melalui kolaborasi antara guru, siswa, dan keluarga.

Peran guru tidak hanya sebatas mengajar siswa, melainkan juga bertanggung jawab mendidik termasuk menjadi model peran dalam melakukan tindakan atau menginisiasi perubahan perilaku sesuai dengan comprehensive school health model yaitu penguatan peran sekolah sebagai tempat terbaik kedua setelah rumah dalam memenuhi kebutuhan anak, termasuk 
kebutuhan gizi. Guru seharusnya berperan aktif dalam upaya promosi kesehatan keamanan makanan siswa. Penelitian ini bertujuan untuk mengidentifikasi pengaruh model Kolaborasi Guru, Siswa, dan Keluarga (KOGUSIGA) terhadap peningkatan pengetahuan dan keterampilan guru tentang keamanan makanan pada siswa sekolah dasar.

\section{Metode}

Desain yang digunakan adalah ujicoba model KOGUSIGA yang telah dikembangkan dengan pendekatan eksperimen semua pre-post test dengan kelompok kontrol. Penelitian dilaksanakan di Depok, Jawa Barat selama tiga bulan. Pengambilan sampel menggunakan teknik total sampling dengan jumlah sampel sebesar 28 responden yang sesuai kriteria inklusi yang terdiri dari 15 responden kelompok intervensi dan 13 responden kelompok kontrol.

Penelitian ini menerapkan prinsip etika penelitian pada responden. Persetujuan etik diperoleh dari Komite Etik Penelitian Fakultas Ilmu keperawatan Universitas Indonesia. Prosedur administratif berupa perizinan pengambilan data di lokasi penelitian juga telah dilakukan.

Data yang dikumpulkan dengan kuesioner berupa pertanyaan dan pernyataan tentang karakteristik demografi responden guru, keluarga, dan siswa; pengetahuan guru, dan keterampilan guru. Pertanyaan demografi guru terdiri dari usia, jenis kelamin, tingkat pendidikan, bidang studi pengajaran, status wali kelas, dan tanggung jawab selain mengajar. Pernyataan tentang pengetahuan guru terdiri dari 25 soal dengan pilihan jawaban ya atau tidak. Pernyataan keterampilan guru dan keluarga ini terkait dengan keterampilan pola hidup bersih sehat (PHBS), bahan makanan aman, pengolahan makanan, penyimpanan makanan, gizi seimbang, kandungan gizi makanan, dan penyajian makanan.

Penelitian ini menggunakan program komputer untuk melakukan analisis. Perubahan yang terjadi sebelum dan sesudah intervensi Model KOGUSIGA dianalalisis menggunakan uji bivariat. Untuk jenis data data numerik pada komparasi dua kelompok berpasangan dengan distribusi data normal menggunakan uji $T$ Paired, sedangkan pada data terdistribusi tidak normal menggunakan alternatif uji Wilcoxon, kedua uji ini dapat diperbandingkan.

\section{Hasil}

Karakteristik respon berdasarkan rerata usia guru pada kelompok intervensi sebesar 43,13 tahun dan tidak jauh berbeda dengan kelompok kontrol sebesar 41,08 tahun. Bidang studi yang diajarkan oleh guru pada kelompok intervensi sebesar 26,7\% mengajar IPS, sedangkan

Tabel 1. Pengaruh Model KOGUSIGA terhadap Pengetahuan dan Keterampilan Guru pada Kelompok Intervensi dan Kelompok Kontrol

\begin{tabular}{|c|c|c|c|c|c|c|c|c|c|}
\hline Kelompok & $\mathbf{n}$ & $\bar{x}$ Pre (\%) & $\mathbf{s}$ & $\underset{* * * * *}{\text { Uji Normalitas }}$ & $\begin{array}{c}\bar{x} \text { Post } \\
(\%)\end{array}$ & $\mathbf{s}$ & $\underset{* * * * *}{\text { Uji Normalitas }}$ & $\begin{array}{c}\% \\
\text { Beda } \bar{x}\end{array}$ & $\begin{array}{l}\text { p-value } \\
\text { 1-tailed } \\
\text { pre-post }\end{array}$ \\
\hline \multicolumn{10}{|l|}{ Pengetahuan } \\
\hline Intervensi & 15 & $14,87(59,48)$ & 2,79 & 0,473 & $18,73(74,92)$ & 3,22 & 0,041 & 15,44 & $0,003 *$ \\
\hline Kontrol & 13 & $17,62(70,48)$ & 2,10 & 0,044 & $18,08(72,32)$ & 2,10 & 0,307 & 1,84 & $0,197 *$ \\
\hline \multicolumn{10}{|l|}{ Keterampilan } \\
\hline Intervensi & 15 & $65,20(65,20)$ & 14,93 & 0,297 & $76,20(76,20)$ & 10,58 & 0,740 & 11,00 & $0,015^{* *}$ \\
\hline Kontrol & 13 & $61,54(61,54)$ & 12,90 & 0,487 & $62,77(62,77)$ & 10,08 & 0,785 & 1,23 & $0,323 * *$ \\
\hline
\end{tabular}

Keterangan: * Wilcoxon Test, ** T-Test Paired, ****T-Test Independent; ***** Shapiro-Wilk Test, s: standar deviasi 
69,2\% pada kelompok kontrol. Tanggung jawab guru selain mengajar adalah sebagai kepengurusan sekolah dimana pada kelompok intervensi sebesar 43,3\% dan pada kelompok kontrol sebesar $61,5 \%$. Hasil uji kesetaraan karakteristik guru antara kelompok intervensi dengan kelompok kontrol tidak berbeda signifikan ( $p>0,05)$ baik dari karakteristik usia, jenis kelamin, tingkat pendidikan, bidang studi pengajaran, dan tanggung jawab selain mengajar.

\section{Pembahasan}

Hasil uji statistik bivariat pengetahuan prepost menunjukkan adanya peningkatan pengetahuan dan keterampilan guru pada kelompok intervensi sebelum dengan sesudah diberikan intervensi secara signifikan, sedangkan pada guru kelompok kontrol tidak terdapat peningkatan secara signifikan. Chen, Soo, Azriani, Van Rostenberghe, dan Sakinah (2012) menyatakan bahwa guru yang diberikan pelatihan lebih percaya diri dan memiliki perasaan tanggung jawab lebih untuk mengembangkan promosi kesehatan kepada siswa. Hasil penelitian ini sesuai dengan hasil penelitian Lee, Jeong, Ko, dan Park, (2016) mengenai edukasi kemananan makanan dan gizi pada sekolah menengah di Korea. Penelitan oleh Chen, et al. (2012) menjelaskan tentang lokakarya gizi pada guru yang hasilnya menunjukan adanya peningkatan pengetahuan, sikap, dan keterampilan guru terkait kebiasaan makan sehat pada anak sekolah. Pada penelitiannya, Lee, et al. (2016) melibatkan guru dalam pemilihan edukasi gizi dan kemanan makanan yang tepat bagi siswa. Hasil akhir penelitiannya menunjukkan adanya perbaikan dalam pemilihan makanan sehat di kalangan siswa.

Peneliti setuju dengan pendapat Lee, et al. (2016); Chen, et al. (2012) yang menyatakan bahwa guru yang diberikan pelatihan lebih percaya diri dan memiliki perasaan tanggung jawab lebih untuk mengembangkan promosi kesehatan kepada siswa. Hal ini ditunjukan pula pada penelitian ini, yaitu pada analisis kuisoner pengukuran keterampilan yang menunjukkan bahwa keterampilan guru dalam memberi edukasi mengenai "dampak negatif bagi kesehatan apabila siswa jajan di sembarang tempat" naik setelah intervensi. Strategi pendidikan kesehatan tentang makanan sehat perlu dikolaborasikan dengan guru (Lisson, et al., 2016). Model KOGUSIGA menjadikan guru sebagai salah satu pemeran utama dalam memberikan pendidikan gizi sebagai usaha meningkatkan pemenuhan gizi siswa yang seimbang. Untuk dapat memberikan pendidikan tersebut, guru dibekali dengan pengetahuan yang memadai melalui pelatihan yang diberikan oleh perawat puskesmas yang bertanggung jawab mengelola UKS.

Pengetahuan guru mengenai penyimpanan makanan di tempat yang bersih, kandungan gizi pada makanan, penyajian makanan yang aman, bahaya penggunaan plastik hitam meningkat secara keseluruhan sesudah pemberian intervensi model KOGUSIGA. Hasil penelitian Rosário, et al., (2013) menyebutkan bahwa guru mampu meningkatkan pengetahuan tentang nutrisi dan kesehatan makanan pada siswa setelah intervensi. Guru diberikan pelatihan terlebih dahulu oleh peneliti lalu memberikan intervensi pada siswa berdasarkan model promosi kesehatan. Sibley, et al. (2017) juga menambahkan peran guru sangan penting dalam upaya meningkatkan kesehatan makanan pada siswa. Hasil penelitian Lynch (2015) juga menunjukkan adanya peningkatan perilaku pemilihan makanan setalah intervensi yang dikolaborasikan bersama guru sekolah melalui lima tahapan pendidikan kesehatan yaitu pengetahuan nutrisi, pemilihan makanan jajanan, memasak, pengetahuan kandungan gizi pada makanan, dan bermain sosiodrama. Hal ini menunjukkan bahwa model KOGUSIGA mendorong pemahaman guru pentingnya menjaga keamanan makanan.

Kemampuan individu dalam pemenuhan gizi sangat dipengaruhi oleh pengetahuan, sikap, dan keterampilan guru, siswa, dan keluarga tentang keamanan makanan (Rosenstock, 1990 
dalam Allender, Rector, \& Warner, 2010). Model KOGUSIGA ini mengadopsi Health Belief Model dengan mempersiapkan anak usia sekolah untuk meningkatkan keterampilan mereka memilih makanan yang aman. Pada model ini dilakukan upaya pemberian pengetahuan tentang makanan yang aman untuk meningkatkan kesadaran akan manfaat yang dirasakan jika guru, siswa, dan keluarga memenuhi kebutuhan gizi yang aman. Persepsi terhadap risiko atau kerentanan yang dirasakan terhadap paparan jajanan yang tidak aman dari lingkungan sekolah mendorong siswa, guru, dan orangtua untuk mengadopsi perilaku yang sehat.

Hasil analisis kuisioner pengukuran pengetahuan post-test menunjukkan semua guru sepakat bahwa "makanan yang disimpan di tempat bersih adalah makanan yang aman" dan "makanan yang sehat adalah makanan yang hanya disajikan secara bersih". Setelah diberikan intervensi kesadaran guru pada bahaya penggunaan plastik hitam sebagai bungkus makanan mengalami peningkatan yang signifikan. Sebelum intervensi jumlah guru yang menjawab benar pada pernyataan "makanan yang disajikan dengan bungkus plastik hitam tidak aman untuk dimakan" sebesar 40\%, setelah intervensi jumlahnya naik menjadi 93,3\%. Meskipun demikian, kesadaran guru pada pengaruh kantin terhadap perilaku jajan siswa masih perlu ditingkatkan.

Pedoman UKS tahun 2012 menyebutkan bahwa pembinaan kantin sekolah sehat merupakan kegiatan promotif yang diutamakan dan merupakan bagian dari pelayanan kesehatan komprehensif di sekolah (Kemendikbud RI, 2012). Hasil penelitian yang dilakukan oleh Finch, Sutherland, Harrison, dan Collins (2006) menunjukkan bahwa kantin sekolah yang sehat akan memengaruhi kesehatan siswa. Siswa sekolah akan cenderung memilih makanan yang disediakan di kantin sekolah sehingga makanan yang disediakan di kantin harus sesuai dengan standar gizi seimbang dan aman. Oleh karena itu, kesadaran guru terhadap hal ini perlu ditingkatkan demi meningkatkan partisipasi guru dalam pengawasan keamanan jajanan sekolah.

Sesudah intervensi model KOGUSIGA, keterampilan guru meningkat dalam memberikan edukasi kepada siswa mengenai dampak negatif jajan sembarang, edukasi makanan sehat kepada pedagang kantin, mengkomunikasikan pemenuhan gizi siswa ke keluarga, mengkomunikasikan masalah perkembangan gizi siswa kepada orang tua, mengkomunikasikan orang tua untuk menyiapkan bekal makanan yang mengandung gizi seimbang dan aman untuk anaknya. Peningkatan keterampilan komunikasi guru ke orang tua tersebut menunjukan adanya kolaborasi antara guru dan orangtua yang dalam model KOGUSIGA ini dilakukan dengan pendidikan kesehatan pada orang tua oleh guru, proses evaluasi buku kerja orangtua/keluarga, dan konsultasi. Hasil penelitian Arcan, et al. (2013), menunujukkan guru mampu meningkatkan keterampilan siswa dalam memilih makanan sehat melalui proses pendampingan kesehatan makanan. Selain itu, penelitian juga didukung oleh Meiklejohn, Hons, Ryan, dan Palermo (2016) yang menyatakan kolaborasi guru, orang tua, staf sekolah, dan siswa mampu menciptakan kantin sehat dan penyediaan makanan jajanan sehat pada siswa berumur 10-18 tahun.

Pada analisis kuisioner pengukuran keterampilan guru didapatkan bahwa Model KOGUSIGA mendorong guru untuk memberikan pelatihan pada pada petugas kantin. Hal ini terlihat dari penurunan jumlah guru yang menjawab "tidak pernah" pada pernyataan "saya memberikan pelatihan bagi petugas kantin". Meskipun demikian, poin tersebut harus tetap ditingkatkan mengingat masih rendahnya pengetahuan pedagang jajanan sekolah mengenai makanan aman. Hasil penelitian Nurkholidah, Ilza, dan Jose (2012) menunjukkan pedagang di lingkungan sekolah dasar yang mengetahui tentang boraks dan bahayanya hanya $29,41 \%$, sedangkan yang tidak mengetahui boraks dan bahayanya sebesar $70,59 \%$. Penelitian itu juga 
menunjukkan hanya $5,88 \%$ pedagang yang pernah mendapat perhatian dari pemerintah terkait sosialisasi kesehatan makanan. Oleh karena itu, peran guru sangat penting dalam upaya peningkatan pedagang jajanan sekolah mengenai makanan aman.

Peningkatan keterampilan guru juga tampak pada keterampilan berkolaborasi dengan Puskesmas untuk menjalankan fungsinya dalam melakukan investigasi mutu jajanan anak di sekolah dan pemeliharaan kantin sehat. Keterlibatan orang tua, lingkungan sekolah, dan kerjasama dengan Puskesmas dalam model KOGUSIGA ini sesuai dengan prinsip UKS yang memiliki nilai ganda, yaitu selain berdampak pada upaya peningkatan derajat kesehatan peserta didik beserta masyarakat sekolah lainnya, juga berdampak terhadap pemberdayaan komunitas sekolah dalam upaya peningkatan derajat kesehatan masyarakat. Pembinaan dan pengembangan UKS di sekolah/ Satuan Pendidikan Luar Sekolah dilaksanakan melalui tiga program pokok yang meliputi pendidikan kesehatan, pelayanan kesehatan, dan pembinaan.

Perubahan positif keterampilan guru lainnya ditunjukan pada poin keterampilan guru dalam mengkomunikasikan pemenuhan gizi siswa ke keluarga. Sebelum intervensi jumlah guru yang menjawab "selalu" dan "sering" pada pernyataan "saya mengkomunikasikan masalah perkembangan gizi siswa kepada orang tua" adalah sebesar $0 \%$ dan $40 \%$, setelah intervensi jumlah guru yang menjawab "selalu" dan "sering" menjadi $46,7 \%$ dan $26,7 \%$. Keterampilan guru dalam mengkomunikasikan "orang tua untuk menyiapkan bekal makanan yang mengandung gizi seimbang dan aman untuk anaknya" mengalami peningkatan. Hal tersebut ditunjukan dengan meningkatnya jumlah guru yang menjawab "selalu" dan "sering" setelah intervensi, yaitu sebesar $53,3 \%$ dan $20 \%$ (sebelum intervensi sebesar $26,7 \%$ dan 40\%). Peningkatan keterampilan komunikasi guru ke orang tua tersebut menunjukkan adanya kolaborasi antara guru dan orangtua yang dalam model KOGUSIGA ini dilakukan dengan pendidikan kesehatan kepada orang tua oleh guru, proses evaluasi buku kerja orang tua/ keluarga, dan konsultasi.

Keterampilan guru yang perlu ditingkatkan yaitu pada poin "menegur siswa yang terlihat jajan sembarangan" dimana setelah intervensi masih ada 26,7\% guru yang jarang atau tidak pernah melakukan keterampilan tersebut. Guru memiliki peran tidak hanya sebatas menjadi tenaga pengajar bagi siswa. Guru juga bertanggung jawab menjadi role model siswa dalam melakukan tindakan. Melalui perannya tersebut, guru tidak hanya dapat menegur siswa yang jajan sembarangan, tetapi juga dapat mengajak siswa untuk duduk makan bersama dan mendiskusikan seperti apa makanan yang layak dan bergizi untuk dimakan (Eliassen, 2011). Tidak hanya sebatas mengajak dan mencontohkan, guru dapat memberikan penghargaan dan reinforcement bagi siswa yang telah mengubah pilihan jajannya ke arah yang lebih baik. Perubahan keterampilan memang dilakukan secara bertahap sesuai dengan transtheoretical model, selama proses perubahan berlangsung perawat sekolah memegang peran untuk memantau dan memastikan perubahan sampai yang tahap yang dituju.

Lingkungan Kehidupan Sekolah Sehat (Kemendikbud RI, 2012), PMK Nomor 75 tentang Puskesmas juga mengamanatkan bahwa pelayanan promosi kesehatan merupakan jenis upaya kesehatan masyarakat yang strateginya dapat dilakukan dengan promosi kesehatan di sekolah pendidikan dasar, edukasi dan konseling mengenai pola makan, perilaku makan dan aktivitas fisik bagi anak usia sekolah. Disinilah perawat kesehatan sekolah dapat berperan sebagai koordinator dalam menjalankan pelayanan promosi kesehatan yang ingin dituju oleh pemerintah. Belum munculnya peran perawat kesehatan sekolah di Indonesia diikuti juga dengan belum adanya peraturan, pedoman, dan persiapan pembentukannya oleh instasi pendidikan keperawatan melalui sebuah kurikulum khusus. 


\section{Kesimpulan}

Model KOGUSIGA merupakan metode pendidikan kesehatan kolaboratif yang melibatkan kerjasama dari seluruh komponen sekolah. Hasil penelitian ini menunjukkan bahwa model KOGUSIGA memberikan pengaruh secara bermakna pada peningkatan pengetahuan dan keterampilan guru di kelompok intervensi. Oleh karena itu, Model KOGUSIGA dapat menjadi variasi intervensi keperawatan sehingga diintegrasikan dalam metode pendidikan kesehatan sebagai upaya program preventif dan promotif Usaha Kesehatan Sekolah (UKS).

Berdasar hasil penelitian yang telah dijabarkan, perawat kesehatan sekolah sangat dibutuhkan keberadaannya sehingga implikasi penelitian ini adalah menginisiasi adanya perawat kesehatan sekolah yang dapat menjalankan asuhan keperawatan sekolah menggunakan strategi intervensi keperawatan komunitas untuk meningkatkan keamanan makanan secara khusus dan kesehatan anak usia sekolah pada umumnya. Kepada Kementerian Kesehatan RI, Kementerian Kebudayaan Pendidikan Dasar dan Menengah, Kementerian Agama, dan Kementerian Dalam Negeri, sebagai pembuat kebijakan terkait program Usaha Kesehatan Sekolah (UKS) dapat memunculkan peran perawat kesehatan sekolah dengan memberdayakan perawat puskesmas sebagai pelaksana program kesehatan sekolah (JH, AYN, INR).

\section{Ucapan Terima Kasih}

Hibah Madya Universitas Indonesia sebagai sponsor penelitian ini.

\section{Referensi}

Allender, J.A., Rector, C., \& Warner, K.D. (2010). Community health nursing: Promoting and protecting the public's health (7th $\mathrm{Ed}$ ). Philadelphia: Lippincott Williams \& Wilkins.
Andarwulan, N., Madanijah, S., \& Zulaikhah. (2008). Laporan penelitian: Monitoring dan verifikasi profil keamanan Pangan Jajanan Anak Sekolah (PJAS) Nasional Tahun 2008. Bogor: Southeast Asian Food and Agricultural Science and Technology (SEAFAST). Center IPB dan Direktorat Surveilan dan Penyuluhan Keamanan Pangan BPOM RI.

Arcan, C., Hannan, P.J., Himes, J.H., Fulkerson, J.A., Rock, B.H., Smyth, M., \& Story, M. (2013). Intervention effects on kindergarten and first-grade teachers' classroom food practices and food-related beliefs in American Indian Reservation Schools. Journal of the Academy of Nutrition and Dietetics, 113 (8), 1076-1083. http://doi.org/10.1016/j.jand.20 13.04.019.

Brown, J.E., Isaacs, J., Krinke, B., Lechtenberg, E., \& Murtaugh, M. (2005). Nutrition through the life cycle (2nd Ed). Wadsworth: USA.

Chen, S.T., Soo, K.L., Azriani, A.R., Van Rostenberghe, H., \& Sakinah, H. (2012). Nutrition knowledge, attitude and practice of teachers in rehabilitation centres in Northern Malaysia. Mal J Nutr, 18 (2), 185-205.

Dinas Kesehatan Kota Depok. (2012). Visi misi Dinas Kesehatan Kota Depok Tahun 2011 2016. Diakses dari http://dinkes.depok.go.id/ index.php/option $=$ com_content\&review $=$ arti cle\&id $=92 \&$ Itemid $=90$.

EFSA. (2012). E.coli: Rapid response in a crisis. Diakses dari http://www.efsa.europa.eu/en/ press/news/120711.htm.

Eliassen, E.K. (2011). The impact of teachers and families on young children's eating behaviors. Young Children. Diakses dari http://www. naeyc.org/files/naeyc/Eliassen_0.pdf

FAO/WHO. (2002). Pan-European conference on food safety and quality. Final Report. Rome: FAO \& WHO.

FAO/WHO. (2004). "Final Report”. FAO/WHO Regional conference on food safety for Asia and the Pacific, held in Seremban, Malaysia, 24-27 May 2004. Rome: FAO/WHO. 
Finch, M., Sutherland, R., Harrison, M., \& Collins, C. (2006). Canteen purchasing practices of year 1-6 primary school children and association with SES and weight status. Aust $N$ Z J Public Health, 30 (3), 247-251. doi:10.1111/j.1467-842X.2006.tb00865.x

Kemendikbud RI. (2012). Pedoman pembinaan dan pengembangan usaha kesehatan sekolah. Jakarta: Direktorat Jenderal Pendidikan Dasar. Diakses dari http://www. usahakesehatansekolah.com/get/ pedomanpembinaan-uks-pdf?code $=$ ffac2f3e099b9950 7 aa185fd84f0339e.

Kementerian Kesehatan RI. (2014). Panduan Gizi Seimbang 2014. Jakarta: Kementrian Kesehatan RI.

Kusumaningsih, I., Sahar, J., \& Mulyono, S. (2010). Pemberdayaan siswa sebagai motivator untuk mencegah gizi kurang pada kelompok anak sekolah dasar ratujaya III di Kelurahan Ratujaya, Kota Depok (Karya Ilmiah Akhir, Program Studi Ners). Fakultas Ilmu Keperawatan Universitas Indonesia, Depok.

Lee, J., Jeong, S., Ko, G., \& Park, H. (2016). Development of a food safety and nutrition education program for adolescents by applying social cognitive theory. Osong Public Health and Research Perspectives, 7 (4), 248-260. http://doi.org/10.1016/j.phrp. 2016.05.005

Lisson, S., Goodell, L.S., Dev, D., Wilkerson, K., Hegde, A.V., \& Stage, V.C. (2016). Nutrition education resources in north carolina-based head start preschool programs: Administrator and teacher perceptions of availability and use. Journal of Nutrition Education and Behavior, 48 (9), 655-663.e1. http://doi.org /10.1016/j.jneb.2016.07.016

Lynch, M. (2015). Kindergarten food familiarization: An exploratory study of teachers' perspectives on food and nutrition in kindergartens. Appetite, 87, 46-55. http://doi.org/10.1016/j. appet.2014.12.200
Meiklejohn, S., Hons, B.N.D., Ryan, L., \& Palermo, C. (2016). Systematic review a systematic review of the impact of multistrategy nutrition education programs on health and nutrition of adolescents. Journal of Nutrition Education and Behavior, 48 (9), 631-646.e1. http://doi.org/10.1016/j.jneb.20 16.07 .015

Nurkholidah, Ilza, M., \& Jose, C. (2012). Analisis kandungan boraks pada jajanan bakso tusuk di sekolah dasar di Kecamatan Bangkinang Kabupaten Kampar. Jurnal Ilmu Lingkungan, 6 (2). ISSN 1978-5283. Diakses dari http:// ejournal.unri.ac.id/index.php/JIL/article/vie wFile/963/956.

NIDM. (2013). Disaster Update. http://nidm.gov.in /PDF/DU/2013/October/24-10-13.pdf.

Rosário, R., Araújo, A., Oliveira, B., Padrão, P., Lopes, O., Teixeira, V., ... Moreira, P. (2013). Impact of an intervention through teachers to prevent consumption of low nutrition, energy-dense foods and beverages: A randomized trial. Preventive Medicine, 57 (1), 20-25. http://doi.org/10.1016/j.ypmed. 2013.02.027

Sibley, E., Theodorakakis, M., Walsh, M.E., Foley, C., Petrie, J., Raczek, A., \& Ed, M. (2017). The impact of comprehensive student support on teachers: Knowledge of the whole child, classroom practice, and teacher support. Teaching and Teacher Education, 65, 145-156. http://doi.org/10.1016/j.tate.20 17.02.012

Siburian. (2012). Pengetahuan anak sekolah dasar terhadap pencegahan penyakit diare di SD 098167 RSS Perumnas Kerasaan Kec. Pematang Badar Kab. Simalungun. Penelitian (Skripsi, Program Studi Sarjana Keperawatan). Universitas Sumatera Utara, Medan.

Wong, D.L., Eaton, M.H., Wilson, D., Winkelstein, M.L., \& Schartz, P. (2008). Buku ajar keperawatan pediatrik wong (Edisi 6, Alih bahasa: Sutarna, A.). Jakarta: EGC. 